\title{
Efektifitas Media Promosi Dalam Meningkatkan Kunjungan Wisata Alam
}

\author{
Zulin Nurchayati \\ Fakultas Ilmu Sosial Dan Ilmu Politik, Universitas Merdeka Madiun, Jl. Serayu No.79, Madiun, 63133 \\ E-mail: zulinnurchayati@unmer-madiun.ac.id
}

\begin{abstract}
Research with the title Effectiveness of Media Promotion in Increasing Natural Tourism Visits in Nongko Ijo Village of Kare, Kec. Kare, Kab. Madiun. This research discusses the extent to which the level of community readiness in developing Nongko Ijo Tourism Village. The data in this study were obtained from direct observation through questionnaires and interviews with the people of Kare Village, Kecamagtan Kare, Madiun Regency. As a tour manager as well as to several tourists who are in the Nongko Ijo Tourism Village. The results of this study indicate that the readiness of the community in developing the Nongko Ijo Tourism Village is very high seen from several aspects, namely, attractions, accessibility, and amenities. The evaluation of this research can be useful for future development. The community participates in developing their village into one of the villages.
\end{abstract}

Keywords_-: Nongko Ijo; Nature Tourism; Forest.

\section{PENDAHULUAN}

Indonesia merupakan negara dengan keanekagaraman hayati berupa sumber daya alam yang berlimpah, baik di daratan, udara maupun di perairan. Sumber daya alamnya dapat meningkatkan pertumbuhan ekonomi bagi warga masyarakat apabila sumber daya tersebut di kelola dengan baik, sesuai dengan apa yang paling diminati dan bisa memberikan daya tarik bagi masyarakat luas. Sekarang ini, memberikan kesempatan kepada setiap pemerintah daerah untuk dapat mengembangkan potensipotensi yang ada di masing-masing dengan tujuan untuk menambah pendapatan asli daerah.

Pariwisata berkembang pesat di era modern ini. Maraknya kegiatan pariwisata menjadi tren yang sangat digandrungi mulai dari remaja sampai dewasa. Seperti yang tertulis di Undang-Undang Nomor 10 Tahun 2009 tentang Kepariwisataan, pariwisata adalah berbagai macam kegiatan wisata yang didukung oleh berbagai fasilitas serta layanan yang disediakan masyarakat, pengusaha, Pemerintah, dan Pemerintah Daerah. Maka penyediaan fasilitas pun sangat penting bagi kepuasan wisatawan. Semakin baik fasilitas yang disediakan maka semakin besar minat wisatawan untuk berkunjung. Menurut Pitana dan Diarta (2009:134) strategi pengembangan pariwisata harus mampu menggabungkan aspek-aspek penunjang kesuksesan dunia pariwisata. Aspek-aspek tersebut adalah aspek transportasi dan saluran pemasaran, infrastruktur pariwisata, interaksi social dan keterkaitan dengan sektor lain, daya tahan terhadap dampak pariwisata, resistensi komunitas lokal dan lain-lain. Menurut Spillane (1994: 63-72) mengatakan bahwa dalam pengembangan suatu objek wisata sebagai daerah tujuan wisata (destination), harus memperhatikan lima unsur penting agar wisatawan dapat merasa puas dalam menikmati perjalanan wisatanya, lima unsur destinasi wisata tersebut meliputi :

1. Daya tarik wisata dan atraksi wisata yang mampu menarik pengunjung

2. Fasilitas yang dapat mendukung kebutuhan dan keperluan wisatawan

3. Infrastruktur dasar yang tersedia untuk kebutuhan wisatawan

4. Transportasi menunjang dan mendukung mobilisasi wisatawan

5. Keramah tamahan masyarakat lokal kepada wisatawan.

Masyarakat beserta pemerintah daerah perlu bekerjasama dalam membangun sebuah desa wisata dengan potensi yang ada. Keterlibatan masyarakat desa sangat dibutuhkan dalam menerima wisatawan. Salah satunya Desa Wisata Nongko Ijo, Desa Kare, Kecamatan Kare, Kabupaten Madiun. Pariwisata yang ada di desa ini cukup menarik. Ditengah ramainya wisata modern, Desa Wisata Nongko Ijo masih mempertahankan eksistensinya sebagai Desa Wisata terbaik dengan konsep "Quiet”. Ditambah lagi banyak diantara calon wisatawan yang menghindari kawasan wisata yang telah sukses atau tempat yang tingkat konsentrasi wisatawannya sangat tinggi, kemudian mencari tempat yang lebih menonjolkan keaslian (autheticity), orisinalitas (originality), dan keunikan (uniqeness) lokal (Reisinger dan Steiner, 2006:Olsen,2002. Potensi alam dan budaya masyarakat setempat menarik wisatawan yang menginginkan suasana berbeda dengan kehidupan di tempatnya. Kesiapan masyarakat dalam menerima kegiatan wisata pun dapat diukur dari fasilitas yang disediakan untuk wisatawan serta peran masyarakat dalam kegiatan pariwisata di desa wisata ini. Oleh karena itu kesiapan masyarakat sangat berpengaruh terhadap pengembangan desa wisata. Disamping dari potensi, sarana dan prasarana pun menunjang nilai sejauh mana peran dan kepedulian masyarakat terhadap tempat wisata tersebut. Dari permasalahan kesediaan masyarakat tersebut kami menentukan judul "Efektifitas Media Promosi Dalam Meningkatkan Kunjungan Wisata Alam Nongko Ijo Desa Kare, Kec.Kare, Kab.Madiun”. 
Website : http://sosial.unmermadiun.ac.id/index.php/sosial

\section{METODE PENELITIAN}

a. Waktu dan Tempat

Penelitian ini dilakukan pada Bulan Agustus 2020 sampai Bulan Desember 2020 di Desa Wisata Alam Nongko Ijo Desa Kare, Kec.Kare, Kab.Madiun.

b. Metode Pengumpulan Data

Sumber Data

1) Data Primer

Metode yang dilakukan adalah observasi langsung di kawasan Desa Wisata Alam Nongko Ijo Desa Kare, Kec.Kare, Kab.Madiun. Komponen yang dinilai adalah:

a) Attraction alam dan budaya meliputi hutan dan air terjun yang dijumpai di desa wisata

b) Accesibility meliputi kondisi jalan, jarak, tipe jalan dan waktu tempuh dari kota

c) Amenity yang berada di sekitar lokasi wisata seperti: jaringan telepon, puskesmas, rumah makan, toilet, dan lainlain.

d) Ancillary yang berada di sekitar lokasi wisata seperti: rel kereta, bank, puskesmas, TIC, dan kelembagaan.

e) Analisis Kesiapan Masyarakat

Data ini diperoleh dengan dua cara yaitu kuesioner terhadap wisatawan dan wawancara terhadap masyarakat di Desa Wisata Nongko Ijo mengenai kesiapan masyarakat dalam pengembangan Desa Wisata Nongko Ijo.

2) Data Sekunder

Data sekunder diperoleh melalui studi pustaka dari berbagai sumber referensi.

\section{III.HASIL DAN PEMBAHASAN}

\section{A. Gambaran Umum Desa Wisata Nongko Ijo Kare}

Kare merupakan desa yang berada di Kecamatan Kare, Kabupaten Madiun, sebelah utara dari Kabupaten Ponorogo, sebelah timur dari Kabupaten Magetan, sebelah selatan dari Kabupaten Nganjuk. Dua tahun terakhir menjadi daerah wisata alam yang menjadi rujukan Kabupaten Madiun dari 31 wisata alam yang ada di Kabupaten Madiun.Luas wilayah Desa Kare 4.176,71 Ha dengan arel terbesar adalah tanah perkebunan dan hutan.

Nongko Ijo Kare memiliki iklim tropis dengan suhu udara rata-rata 23 0C dan rata-rata terendah sekitar 20 0C. November menjadi bulan terpanas sepanjang tahun dan Juli adalah suhu rata-rata terendah. Secara umum, bahasa daerah yang digunakan di Nongko Ijo adalah Bahasa Jawa. Namun dalam perkembangannya, telah banyak yang menggunakan Bahasa Indonesia untuk komunikasi, terutama bagi mereka yang sering berhubungan dengan wisatawan.

Wisata alam Nongko ijo sangat indah dengan segala bentuk pohon hutan yang menghiasi tempat wisata sehingga menjadi tempat wisata handal di Kabupaten Madiun.

\section{B. Atraksi Wisata}

Atraksi wisata merupakan suatu pertunjukan atau tontonan yang memiliki daya tarik besar atau sangat menarik perhatian disuatu kawasan wisata yang menjadi poin utama bagi keberlangsungan pariwisata didareah tersebut.

Atraksi wisata yang terdapat di Desa Nongko Ijo Kare meliputi :

\section{Pemandangan alam}

Pemandangan alam merupakan keindahan alam yang dapat dideskripsikan melalui komponen mata dan panca indra manusia itu sendiri. Pemandangan alam yang terdapat di Desa Nongko Ijo Kare menarik bagi wisatawan hal ini dijelaskan karena kawasan alam masih bersih dan masih terjaga keasliannya tanpa adanya campur tangan manusia.

\section{Hutan}

Kawasan hutan di desa Nongko Ijo Kare cukup menarik untuk dikunjungi wisatawan karena masih terjaga sedemikian rupa oleh masyarakat adat desa Nongko Ijo Kare sendiri. Pembangunannya dan pelestariannya atas partisipasi masyarakat lokal, yang masih kental dengan adat mereka. Dari mulai operator diving yang dibatasi, jumlah hotel, hingga pedagang pun dibatasi oleh peraturan adat. Di desa ini hanya ada sekitar 5 homestaynya.

3. Budaya

Desa Nongko Ijo Kare memiliki nilai budaya yang sangat kental baik dari adat istiadatnya,dan juga upacara keagamaannya. Banyak tamu asing yang penasaran untuk melihat secara langsung acara sacral yang ada di desa Nongko Ijo Kare. Berbagai macam kesenian tersaji dan ditampilkan pada waktu tertentu ataupun pada saat dibutuhkan. Misalnya, Jatil, reyog, gambyong, karawitan. Dongkrek, thok thok Brok maupun kesenian pencak silat juga ada. Karerna Kare merupakan Desa yang menjadi Pusat Perguruan Pandan Alas se- Indonesia. 
Website : http://sosial.unmermadiun.ac.id/index.php/sosial

\section{Air Terjun di bawah hutan dan Hutan Pinus}

Kondisi hutan di desa Nongko Ijo Kare menarik untuk dikunjungi karena banyak menyimpan keunikan tersendiri yang tentunya tidak dapat dijumpai dimanapun selain di Nongko Ijo Kare. Hal ini dijelaskan karena hutan terdapat arsitektur pohon pinus yang di susun sedemikian rupa di wilayah hutan Nongko Ijo Kare. Hutan Pinus menjadi sangat asri dan sejuk terdapat di hamparan dengan dikelilingi hutan jati dan di bawahnya terdapat air terjun yang meski tidak besar tetapi sangat menunjang kondisi wisata alam yang sangat mengesankan bagi para wisatawan

\section{Kuliner Khas}

Kare tidak hanya terkenal akan wisata budaya, alam, dan air terjun saja. Wisatawan juga dapat menikmati kuliner yang terdapat di Nongko Ijo Kare, salah satu kuliner yang menarik perhatian adalah Nasi suweg merupakan salah satu ikon kuliner di Nongko Ijo Kare yang banyak di gemari oleh wisatawan karena akan keunikan rasa dan juga cara penyajiannya yang tradisonal. Selain itu ada jajanan khas Kare yaitu kemplang Kare, Bolu kelapa Kare, coklat dan kopi bubuk kare. Selain itu terdapat berbagai macsm buah sensasional yaitu duren, manggis, degan, pete, jengkol, rambutan, alpokat, kolang kaling dan jeruk keprok, serta ketela dan makanan khas lain produk dari masyarakat Kare yang dikelola oleh UKM Desa Kare.

\section{Oleh - oleh khas}

Oleh - oleh khas yang ada di Kare adalah Kopi Kare yang terkenal sampai manca negara. Nikmatnya kopi Kare bisa diminum diminum di tempat wisata ataupun bisa dibawa pulang sebagai oleh - oleh khas Kare disertai dengan kemplang Kare dan Madu Kare. Selain itu berbagai macam bunga indah bias untuk oleh - oleh dari Kare karena di Kare banyak tumbuh bunga - bunga yang indah berwarna warni.

\section{Aksesbilitas menuju desa Wisata Nongko Ijo Kare}

Aksesbilitas adalah derajat kemudahan bagi wistawan untuk mencapai suatu objek, pelayanan, atau lingkungan. Kemudahan akses tersebut diimplementasikan pada pembangunan gedung, lingkungan dan fasilitas umum lainnya dengan tersedianya berbagai rute alternatif menuju suatu tempat. Model aksesbilitas tersebut bisa dibuat untuk pengguna kendaraan pribadi maupun pengguna kendaraan umum. Secara lebih mudah aksesbilitas dapat dihitung atas dasar panjang perjalanan per kilometer persegi, apabila semakin panjang maka semakin tinggi pula aksesbilitasnya.

Berikut merupakan aksesbilitas menuju desa Nongko Ijo Kare:

\section{Jalan masuk}

Jalan masuk menuju Nongko Ijo Kare cukup mendukung karena dapat ditempuh melalui jalur darat sekitar 25 kilometer dari Ibu Kota Kabupaten Madiun. Meskipun jalannya agak sempit dan naik turun, akan tetapi sepanjang jalan sangat mendukung untuk mencapai tempat wisata Nongko Ijo. Selain itu sepanjang jalan sudah ter aspal semua sampai tujuan dan tidak rawan longsor ataupun banjir.

\section{Petunjuk arah}

Petunjuk arah yang terdapat di desa Nongko Ijo Kare masih kurang mendukung. karena kurangnya ketersedian yang diberikan oleh pihak Pemerintah Desa dan Pokdarwis dalam pengelolaan sehingga jarang kita temui adanya petunjuk arah menuju suatu destinasi yang diinginkan oleh wisatawan. Petunjuk arah hanya ada satu di depan Pemerintah Kecamatan Kare sebagai petunjuk arah umum jika orang masuk ke wilayah Kare.

\section{Penerangan}

Kurangnya penerangan jalan menuju desa Nongko Ijo Kare menjadi salah satu kendala yang sedang dihadapi oleh pengelola. Hal tersebut dapat dilihat melalui lampu lampu jalan yang masih sangat minim dijumpai disekitar kawasan wisata tersebut. Bahkan kalua sore menjelang malam sudah gelap gulita dan tidak bisa menikmati suasana hutan pinus Nongko ijo, sehingga kalau sore jam 17.00 WIB sudah ditutup dan kulinerpun ikut tutup karena sepi. Tetapi sepanjang jalan menuju Nongko ijo sudah diberi penerangan lampu sudah cukup bagus meskipun hanya beberapa titik untuk bisa diakses masyarakat setempat.

\section{E. Amenitas di desa wisata Kare}

Amenitas adalah berbagai fasilitas di luar akomodasi yang dapat dimanfaatkan wisatawan selama berwisata di suatu destinasi. Berikut merupakan beberapa amenitas yang terdapat di desa Nongko Ijo Kare berdasarkan kondisi fisik, kondisi kebersihan, dan kondisi kepuasan dalam pembangunan :

\section{Parkir}

Untuk lahan parkir di desa Nongko Ijo Kare dapat dikatakan kurang baik karena, tidak tersedianaya lahan parkir umum yang dikususkan untuk wisatawan. Sehingga banyak wisatawan yang memarkirkan kendaraannya secara tidak teratur 
Website : http://sosial.unmermadiun.ac.id/index.php/sosial

atau disembarang tempat yang tidak semestinya. Akan tetapi pengelola parkir juga menyediakan tempat meski sempit untuk sepeda motor, sedangkan untuk mobil diatur dipinggir jalan sepanjang jalan menuju Nongko Ijo Kare.

\section{Warung}

Ketersedian warung di Nongko Ijo Kare sudah baik dalam arti sudah cukup dalam jumlahnya, sehingga wisatawan yang datang berkunjung tidak perlu susah untuk mencari warung terdekat guna ingin memenuhi kebutuhan penunjang lainnya. Warung - warung yang ada di sepanjang jalan Nongko ijo adalah warung masyarakat karena di Wilayah Kecamatan Kare belum ada warung modern ataupun toko modern yang menyediakan berbagai macam kebutuhan terkini dalam pasar perdagangan di Wilayah Kecamatan Kare.

\section{Pusat informasi}

Untuk pusat informasi di desa Nongko Ijo Kare sendiri sudah cukup baik karena sudah adanya beberapa kantor yang dikususkan sebagai pusat informasi di desa Nongko Ijo Kare itu sendiri. Salah satu pusat informasi yang terdapat di desa Nongko Ijo Kare adalah Kantor Pemerintah Desa Kare, Kantor Kecamatan Kare, disana wisatawan bisa mendapatkan informasi mengenai wisata di Wilayah Kecamatan Kare. Kabupaten Madiun.

\section{Penginapan}

Untuk saat ini desa Nongko Ijo Kare telah menyediakan 4 homestay yang telah disediakan dari rumah - rumah penduduk setempat.. Saat inidi Kare belum tersedia hotel - hotel untuk penginapan. Akan tetapi ada suatu tempat khusus berupa villa Kandangan yang mempunyai 60 kamar dengan fasilitas Gedung pertemuan yang besar dan megah, juga fasilitas fasilitas tempat wisata di sekitarnya karena berada di puncak lereng wilis.

\section{Tempat ibadah}

Tempat ibadah di lokasi Kare sudah cukup baik dan cukup banyak, karena sudah ada beberapa bangunan tempat ibadah yang berdiri disekitar kawasan Desa Kare contohnya seperti Masjid sudah ada di setiap Dusun dan Musholla hamper di tiap RT.

\section{Jalan setapak/jembatan}

Jalan setapak yang terdapat di desa Nongko Ijo Kare untuk saat ini sudah cukup baik karena, sudah adanya beberapa pembangunan baik aspal sepanjang jalan ataupun selokan air yang cukup memadahi yang dilakukan oleh pihak pengelola. Tetapi tetap saja yang menjadi kendala untuk saat ini adalah kurangnya partisipasi pemerintah dalam pembangunan ataupun pengenbangan pariwisata di desa Nongko Ijo Kare itu sendiri. Ada beberapa alasan yang disampaikan sehubungan dengan dukungan pemerintah yaitu karena tempat wisata Nongko Ijo sudah dianggap mandiri dengan anggota Pokdarwisnya sehingga pemerintah mendukung untuk sarana dan prasarana secara eksternal di luar lokasi Nongko Ijo tetapi tetap dalam Desa Kare.

\section{Analisis SWOT}

Analisis yang digunakan untuk mengetahui kesiapan masyarakat di Desa Wisata Nongko Ijo Kare ini dengan memanfaatkan kekuatan dan meminimalkan kelemahan dari faktor internal serta memanfaatkan peluang yang ada dan menghindari ancaman dari faktor eksternal.

\begin{tabular}{|c|c|c|}
\hline Eksternal & $\begin{array}{l}\text { Kekuatan } \\
\text { 1. Sosial budaya masih melekat pada } \\
\text { kehidupan masyarakat } \\
\text { 2. Keterbukaan masyarakat terhadap } \\
\text { wisatawan } \\
\text { 3. Sesuai dengan konsep tenang, tidak ada } \\
\text { pedagang asongan di Desa Nongko Ijo Kare } \\
\text { 4. Masyarakat terlibat dalam kegiatan dan } \\
\text { pengelolaan wisata } \\
\text { 5. Terdapat Kelompok Sadar Wisata atau } \\
\text { Pokdarwis sebagai organisasi wisata } \\
\text { masyarakat } \\
\text { 6. Lingkungan yang masih asri dan segar } \\
\text { 7. masih banyak sumber daya alam lain } \\
\text { yang bisa dikelola } \\
\text { 8. Banyaknya kesenian yang bisa } \\
\text { ditampilkan } \\
\text { 9. Perhutani sangat mendukung hutan } \\
\text { sebagai tempat wisata alam } \\
\text { 10. Masyarakatnya aktif dan kreatif } \\
\end{array}$ & $\begin{array}{l}\text { Kelemahan } \\
\text { 1. Kurangnya penerangan } \\
\text { 2. Jauh dari pusat pemerintahan Kabupaten } \\
\text { Madiun } \\
\text { 3. Jalan yang ada di Kare naik turun } \\
\text { sehingga memerlukan sopir yang handal } \\
\text { 4. Belum adanya transportasi umum } \\
\text { 5. Kurangnya ekonomi untuk meningkatkan } \\
\text { pembangunan yang banyak adalah ekonomi } \\
\text { rumahan } \\
\text { 6. Kurangnya respon pemerintah terkait } \\
\text { pembangunan infrastruktur } \\
\text { 7. Kurang adanya ide atau inovasi untuk } \\
\text { pengelolaan tempat wisata sehingga } \\
\text { menjadi lebih menarik dan mengesan } \\
\text { 8. Kurang adanya kerjasama dari wisatawan } \\
\text { dalam menjaga dan melestarikan tempat } \\
\text { wisata supaya tetap indah dan asri, dg tidak } \\
\text { menghiraukan larangan ataupun himbauan } \\
\text { yang telah dipasang }\end{array}$ \\
\hline
\end{tabular}


Website : http://sosial.unmermadiun.ac.id/index.php/sosial

\begin{tabular}{|c|c|c|}
\hline $\begin{array}{l}\text { Peluang } \\
\text { 1. Minat wisatawan yang bergeser } \\
\text { kepada konsep pedesaan } \\
\text { 2. Akses menuju Desa Kare relatif } \\
\text { mudah } \\
\text { 3. Berada di Wilayah Kabupaten } \\
\text { Madiun } \\
\text { 4. Banyaknya produk UKM Desa } \\
\text { Kare }\end{array}$ & $\begin{array}{l}\text { Strategi SO } \\
\text { 1. Meningkatkan kreatifitas kegiatan wisata } \\
\text { alam dan budaya pedesaan } \\
\text { 2. Mempromosikan kegiatan olahraga } \\
\text { ( senam. Jalan setapak, pendakian ) kepada } \\
\text { wisatawan yang dating } \\
\text { 3. Membuat icon produk daerah wisata yang } \\
\text { sangat khas yaitu Kopi Kare dengan } \\
\text { membangun gallery yang menjual produk- } \\
\text { produk makanan ataupun jajanan khas Desa } \\
\text { Kare }\end{array}$ & $\begin{array}{l}\text { Strategi WO } \\
\text { 1. Menyediakan transportasi angkutan ojek } \\
\text { bagi wisatawan yang datang ke Nongko Ijo } \\
\text { Kare } \\
\text { 2. Meningkatkan pemberdayaan masyarakat } \\
\text { di Desa Nongko Ijo Kare agar lebih mandiri } \\
\text { 3. meningkatkan tanggung jawab } \\
\text { masyarakat untuk ikut memiliki wisata } \\
\text { dengan mendapatkan manfaatnya }\end{array}$ \\
\hline $\begin{array}{l}\text { Ancaman } \\
\text { 1. Wisatawan yang melanggar } \\
\text { aturan budaya setempat } \\
\text { 2. Pengaruh gaya hidup } \\
\text { wisatawan } \\
\text { 3. Masuknya investor luar yang } \\
\text { menguasai daerah wisata }\end{array}$ & $\begin{array}{l}\text { Strategi ST } \\
\text { 1. Mengadakan kerjasama dengan destinasi } \\
\text { wisata yang berdekatan } \\
\text { 2. Mengembangkan penghijauan yg } \\
\text { menunjang desa wisata } \\
\text { 3. Kerjasama dengan biro wisata untuk } \\
\text { keliling wisata se-Kecamatan Kare sehingga } \\
\text { menjadi wisata keliling Kare } \\
\text { 4. Mendirikan IO untuk acara outbond di } \\
\text { alam terbuka }\end{array}$ & $\begin{array}{l}\text { Strategi WT } \\
\text { 1. Meningkatkan dan merancang media } \\
\text { promosi menggunakan teknologi yang } \\
\text { mudah diakses publik } \\
\text { 2. Menambah atraksi wisata } \\
\text { 3. Meningkatkan kualiatas SDM dengan } \\
\text { mengadakan training } \\
\text { 4. mengadakan pelatihan pemberdayaan } \\
\text { ekonomi masyarakat dalam menunjang } \\
\text { daerah wisata }\end{array}$ \\
\hline
\end{tabular}

\section{F. Analisis Participatory Rural Appraisal.}

Desa Wisata Nongko Ijo Kare dapat dikatakan sudah memenuhi kriteria Desa Wisata yang baik dan layak. Masyarakat desa Kare pun ikut mengelola dan terlibat dalam kegiatan pariwisata di Desa Nongko Ijo Kare. Kerjasama antar masyarakat sangat diperlukan untuk kelangsungan kegiatan pariwisata di Desa Nongko Ijo Kare. Untuk menganalisis kesiapan masyarakat dapat dikaji melalui metode pendekatan partisipatif atau Participatory Rural Appraisal.

\section{G. Karakteristik Sosial Budaya Masyarakat Desa Wisata Nongko Ijo Kare}

Bahasa daerah yang digunakan di Nongko Ijo Kare adalah Bahasa Jawa. Namun dalam perkembangannya, telah banyak yang menggunakan Bahasa Indonesia untuk komunikasi. Di tahun 2020 jumlah penduduk Desa Kare mencapai 6.781 jiwa. Jumlah penduduk laki-laki sebanyak 3370 jiwa dan jumlah penduduk perempuan sebanyak 3411 jiwa dengan jumlah kepala keluarga sebanyak $2482 \mathrm{KK}$.

\begin{tabular}{|c|c|c|}
\hline NO & AGAMA & JUMLAH PENGANUT \\
\hline 1 & HINDU & 2 orang \\
\hline 2 & ISLAM & 6676 orang \\
\hline 3 & KATHOLIK & 3 orang \\
\hline 4 & PROTESTAN & 100 orang \\
\hline 5 & BUDHA & 0 orang \\
\hline \multicolumn{2}{|r|}{ JUMLAH } & 6.781 orang \\
\hline
\end{tabular}

\section{H. Karakteristik Sosial Ekonomi Masyarakat Desa Nongko Ijo Kare}

Adapun rincian mata pencaharian penduduk Desa Nongko Ijo Kare adalah: sebagai petani sebanyak 553 orang, buruh tani sebanyak 58 orang, pegawai negeri sipil sebanyak 37 orang, pengrajin industri rumah tangga sebanyak 15 orang, pedagang keliling sebanyak 23 orang, peternak sebanyak 652 orang, nelayan sebanyak 0 orang, montir sebanyak 6 orang, pembantu rumah tangga sebanyak 5 orang, TNI sebanyak 2 orang, POLRI sebanyak 2 orang, pensiunan PNS/TNI/POLRI sebanyak 35 orang, karyawan perusahaan swasta sebanyak 85 orang, karyawan perusahaan pemerintah sebanyak 14 orang, wiraswasta sebanyak 180 orang, karyawan swasta sebanyak 59 orang, pedagang barang kelontong sebanyak 88 orang, guru swasta sebanyak 6 orang, tukang kayu sebanyak 10 orang, tukang batu 25 orang, tukang cuci 3 orang, seniman sebanyak 51 orang, dukun tradisional 7 orang, pengobatan alternative 1 orang, tidak mempunyai pekerjaan tetap sebanyak 895 orang, belum bekerja sebanyak 185 orang, dan pelajar sebanyak 1112 orang. Ibu Rumah Tangga 2400 orang.

\section{Karakteristik Pendidikan Masyarakat Desa Kare}

Jumlah Penduduk Desa Nongko Ijo Kare Menurut Jenis Pendidikan.
\begin{tabular}{|c|l|c|}
\hline NO & JENIS PENDIDIKAN & JUMLAH \\
\hline 1 & $\begin{array}{l}\text { Belum tamat } \\
\text { SD/sederajat }\end{array}$ & 187 orang \\
\hline 2 & SD/sederajat & 709 orang \\
\hline 3 & SLTP & 1.202 orang \\
\hline 4 & SLTA & 1.117 orang \\
\hline
\end{tabular}


Website : http://sosial.unmermadiun.ac.id/index.php/sosial

\begin{tabular}{|l|l|c|}
\hline 5 & D1/D2 & 32 orang \\
\hline 6 & D3 & 56 orang \\
\hline 7 & S1 & 213 orang \\
\hline 8 & S2 & - \\
\hline 9 & Tidak/belum sekolah & 110 orang \\
\hline \multicolumn{2}{|c|}{ JUMLAH } & 3.626 orang \\
\hline \multicolumn{2}{|c|}{ Sumberdata: Buku Profil Desa Kare (2020). }
\end{tabular}

\begin{tabular}{|l|l|}
\hline Aspek yang dinilai & Uraian \\
\hline \multirow{5}{*}{ Konflik } & $\begin{array}{l}\text { Hanya ada konflik-konflik kecil, seperti perbedaan pendapat dan pelanggaran aturan. Contoh pernah ada } \\
\text { wisatawan yang membawa mobil van untuk menginap didalamnya dan meminta tempat tertentu tanpa } \\
\text { menghubungi masyarakat. Dan mereka menolak, karena kemungkinan besar ada efek negatifnya. } \\
\text { Ada juga konflik yang membawa gaya hidup wisatawan untuk terjun ke masyarakat, sehingga terjadi } \\
\text { perbedaan pendapat yang menyangkut nilai - nilai etika dalam bermasyarakat, }\end{array}$ \\
\hline Kerjasama & $\begin{array}{l}\text { Untuk sekarang ini kerjasama belum ada, tapi untuk mempromosikan masing - masing anggota UKM yang } \\
\text { ada di Desa Nongko Ijo Kare wajib mempromosikan tempatnya sendiri, Karena persaingan yang ketat, mereka } \\
\text { mempromosikan kualitas produk mereka, lalu homestay. Mereka juga bisa mengemas produk mereka dengan } \\
\text { cara masing - masing. Untuk kerjasama, sebagian besar Desa Nongko Ijo Kare bekerja sama dengan agen - } \\
\text { agen toko. }\end{array}$ \\
\hline Pengelola & $\begin{array}{l}\text { Masyarakat terjun langsung dalam pengelolaan Desa Wisata Nongko Ijo Kare. Karena awal mula terbentuknya } \\
\text { Desa Wisata Nongko Ijo Kare ini adalah masyarakat yang memulai dan bukan program Pemerintah. } \\
\text { Masyarakat bertukar ide di suatu waktu untuk membicarakan mengenai hal apa yang akan dikembangkan di } \\
\text { Desa Wisata Nongko Ijo Kare. Akhirnya dibentuk Pokdarwis atau Kelompok Sadar Wisata }\end{array}$ \\
\hline \multirow{5}{*}{ Partisipasi } & $\begin{array}{l}\text { Poin pertama munculnya desa Nongko Ijo Kare karena ekowisata dan keikutsertaan masyarakat untuk } \\
\text { bergotong royong untuk pembersihan fasilitas pariwisata yang ada. Mereka mengundang masyarakat dan } \\
\text { pengusaha untuk melakukan kegiatan positif. Kegotongroyongan masyarakat tidak hanya dalam bentuk tenaga } \\
\text { tetgapi juga konsumsi dan promosi }\end{array}$ \\
\hline
\end{tabular}
Hasil uraian wawancara dengan pengelola Desa Wisata Nongko Ijo Kare

\section{J. Hasil PRA tentang kesiapan masyarakat dalam pengembangan Desa Wisata Kare}

Penerapan metode Participatory Rural Appraisal (PRA) merupakan salah satu strategi untuk memberdayakan masyarakat. PRA menekankan dalam proses pemberdayaan dan peningkatan partisipasi pada keterlibatan masyarakat Desa Nongko Ijo Kare dalam keseluruhan kegiatan perencanaan untuk pengembangan desa wisata.

Hasil Participatory Rural Appraisal Desa Wisata Nongko Ijo Kare disajikan dalam bentuk tabel dibawah ini:

\begin{tabular}{|c|l|l|l|}
\hline No & Aspek yang dinilai & Kondisi Masyarakat & Solusi dari hasil PRA \\
\hline 1 & Ekonomi & $\begin{array}{l}\text { Masyarakat masih membutuhkan dana pemerintah } \\
\text { untuk membangun infrastruktur }\end{array}$ & $\begin{array}{l}\text { Membuat proposal dana dan dana yang } \\
\text { telah diberikan oleh Pemerintah hendaknya } \\
\text { digunakan sesuai dengan keperluannya dan } \\
\text { harus adanya transparansi dana }\end{array}$ \\
\hline 2 & Sosial Budaya & $\begin{array}{l}\text { Masyarakat masih mempertahankan adat istiadat } \\
\text { budaya setempat dan tidak terpengaruh gaya } \\
\text { hidup wisatawan yang berkunjung serta tingginya } \\
\text { dukungan masyarakat dalam pariwisata. Namun } \\
\text { tidak seluruhnya masyarakat memiliki } \\
\text { pengetahuan pariwisata }\end{array}$ & $\begin{array}{l}\text { Pemerintah dan Masyarakat Bersama - } \\
\text { sama dalam meningkatkan SDM dengan } \\
\text { memberikan pelatihan pada masyarakat } \\
\text { sehingga mereka akan memahami dan } \\
\text { terlibat dalam rencana kegiatan } \\
\text { pengembangan pariwisata di Desa Wisata } \\
\text { Nongko Ijo Kare }\end{array}$ \\
\hline \multirow{3}{*}{3} & Pengelola & $\begin{array}{l}\text { - Masyarakat tidak seluruhnya terlibat dalam } \\
\text { pengelolaan pariwisata Desa Nongko Ijo Kare dan } \\
\text { tetap melibatkan Pokdarwis } \\
\text { - Membuat Media promosi yang spektakuler di } \\
\text { tempat - tempat yang strategis }\end{array}$ & $\begin{array}{l}\text { - Masyarakat yang tidak terlibat dalam } \\
\text { sektor pariwisata bisa menjadi penunjang } \\
\text { kembuka usaha dagang dan jasa } \\
\text { - membuat web tersendiri untuk wisata } \\
\text { alam Nongko ijo, membuat media Baleho } \\
\text { di dekat Pemerintah Kecamatan Kare } \\
\text { ataupun sepanjang jalan masuk Kare }\end{array}$ \\
\hline 4 & $\begin{array}{l}\text { Pengelolaan yang } \\
\text { diharapkan }\end{array}$ & $\begin{array}{l}\text { Meningkatkan kegiatan pariwisata yang bernilai } \\
\text { positif tanpa mengurangi nilai-nilai sosial budaya } \\
\text { yang terdapat di Desa Wisata Nongko Ijo Kare }\end{array}$ & $\begin{array}{l}\text { Kegiatan yang dilakukan harus } \\
\text { disampaikan secara terbuka dengan adanya } \\
\text { komunikasi yang partisipatif }\end{array}$ \\
\hline
\end{tabular}

Diharapkan dengan adanya metode Participatory Rural Apprasial ini, masyarakat dapat lebih mengetahui aspek apa yang masih dapat dikatakan kurang maksimal guna mengembangkan pariwisata di Desa Wisata Nongko Ijo Kare 
Website : http://sosial.unmermadiun.ac.id/index.php/sosial

\section{IV.KESIMPULAN DAN SARAN}

\section{A. Kesimpulan}

1. Antraksi di Desa Wisata Nongko Ijo Kare sudah baik,akan tetapi masih banyak potensi yang belum dikelola dengan baik oleh masyarakat setempat.

2. Kesiapan masyarakat di Desa Nongko Ijo Kare sudah tinggi. Masyarakat akan mampu berpatisipasi dan bersaing dengan wisata lain nya di masa yang akan datang.

3. Kurangnya campur tangan pemerintah terhadap pembangunan insfrastruktur yang ada di Desa Nongko Ijo Kare.

4. Sangat perlunya dibuatkan Media promosi yang spektakuler dan bisa menyedot perhatian para wisatawan baik secara on line maupun offline.

\section{B. Saran}

Sangat diperlukan adanya inisiatif dari Pemerintah Daerah untuk mengelola, mengembangkan, dan melestarikan Desa Wisata Nongko Ijo Kare. Selain itu juga diperlukannya bantuan dalam promosi wisata Alam Nongko Ijo secara serentak baik di Media Sosial secara on line maupun cetak dan elektronik.

\section{UCAPAN TERIMA KASIH}

Penulis ucapkan terima kasih kepada para pihak yang telah membantu terselesaikannya penelitian ini, Bapak H.Tarnu Ashidiq, M.Si. (Camat Kare), Bapak Kades Kare H.Sunarno, Pokdarwis Nongko Ijo Kare, Ketua UKM Kare dan seluruh masyarakat Desa Kare.

\section{DAFTAR PUSTAKA}

Pitana, I Gede dan Surya Dikarta, I Ketut, 2009, Pengantar Ilmu Pariwisata, Yogyakarta, Penerbit Andi. Profil Desa Kare Tahun 2020

Reisinger,Y.C.J.Steiner, ( 2006 ), Conceptualizing object authenthicity, Annals of Tourism Research

Spillane, James, 1994. Pariwisata Indonesia dan Perkembangannya, Kanisius, Yogyakarta

Undang - undang No 10 Tahun 2009 Tentang Kepariwisataan

Yoeti, O. A. (2008). Perencanaan Dan Pengembangan Pariwisata. Jakarta: PT Pradnya Paramita. 